\title{
URBAN TRANSFORMATION
}

\author{
A NOTE ON THE OBJECTS OF STREET IMPROVEMENT
}

IN REGENCY AND EARLY VICTORIAN LONDON

The gradual acceptance by politically influential people of the belief that deliberate control of town growth was both feasible and fruitful is a theme in the history of town planning which has many aspects. The transformation of nineteenth century cities by means of street improvement was one of these; and Mr. David Pinkney has recently made a mature assessment of the range of motives underlying the sweeping changes wrought in the configuration of Parisian streets under the Second Empire. ${ }^{1}$ By contrast with Paris under the prefecture of Baron Haussmann, the transformation of London was tentative, not to say hesitating, and not undertaken for all the same reasons. In Paris, Mr. Pinkney has shown that political and strategic aims were mixed with desires for aesthetic and social amelioration. "In London", Napoleon III is reported as saying, "they are concerned only with giving the best possible satisfaction to the needs of traffic." But were they? It is the purpose of this brief note to comment on the validity of this assertion, and in doing so to illustrate an early approach to matters of urban improvement which are still at the heart of some contemporary town-planning problems.

The most dramatic scenic transformation of London before midcentury had occurred in the West End in the cutting of Regent Street after 1814. This was as much the personal triumph of John Nash's indispensable patron, the Prince Regent - later George IV - as it was a consummate display of his own architectural virtuosity. Even in its uncompleted state, Nash's plan was an unparalleled achievement which inevitably dwarfed the modest achievements which followed. But it was also different in another way. For its genesis, which dated from the end of the eighteenth century, lay quite simply in the deter-

1 David H. Pinkney, Napoleon III's Transformation of Paris : the Origins and Development of the Idea, in: Journal of Modern History, xxvii (I955), pp. I 25-34. 
mination of John Fordyce, as Surveyor General of Crown Lands, to augment the Crown's landed revenues.

It was for this reason that Fordyce had first proposed, in 1793 , the compilation of an accurate map of "Marybone Park" and district (being the greatest of the Crown's metropolitan estates), which should form the basis of an open competition for the future development of that area. ${ }^{1}$ His Majesty's Commissioners of Woods, Forests, and Land Revenues clarified these intentions when, in employing their own departmental architects to prepare schemes, they observed that "the present distance, and, in many parts, mean and inconvenient access, from Marybone Park to the parts of Westminster between that and the Thames, are manifest drawbacks on the value of the Estate; and a more direct and commodious line of communication, while it would enhance that value, would also improve to a great extent that of other property, both of the Crown and Individuals, situated in the above district." ${ }^{2}$ Nash himself expressed a similar view when he said, "The main object of the Crown, I conceive to be, the Improvement of their own Estate, to augment and not to diminish it, and not to sell any part of it; a magnificent and convenient Street for the Public will be the result, not the cause... If the whole Street had passed through Property not belonging to the Crown, it might become a nicer question, whether the object in view was commensurate with the expense... but it fortunately happens that four out of five of the property through which the Street will pass belong to the Crown, and the greater part of the rest to the Duke of Portland, who will be as much benefited as the Crown itself; seeing that it leads into the very heart of his best property, Portland Place, to which there is, at present, no appropriate access. The Crown property consists, principally, of old ruinous Houses laid out in narrow streets, the greater part not worth repair, many of them in ruins, the Leases of which are continually falling in; independently, therefore, of considerations belonging to Marybone Park, it would be the interest of the Crown, instead of renewing the Leases of these old Houses, to take them down, form a better arrangement of wider streets, and let the Ground on Building Leases." 3 What sparked the tinder of the Prince Regent's architectural aspirations was apparently the increasing demand for houses in a crowded metropolis which the rapidly expanding suburbs only partly met. And what largely determined the locality of Regency

1 His four reports were reprinted in British Parliamentary Papers, I812 (274), xii.

${ }^{2}$ First Report, H. M. Commissioners of Woods, Forests, and Land Revenues, British Parliamentary Papers, I 8 I 2 (357), xii, pp. 9-I 2.

3 Second Report, H. M. Commissioners of Woods, Forests, and Land Revenues, British Parliamentary Papers, I 816 (147), xv, pp. I 22-3. 
street improvements was the distribution of Crown property, for these improvements were conducted as normal estate development, paid for out of the ordinary landed revenues. ${ }^{1}$

The line the new Regent Street actually took was, as John Summerson has pointed out, an empirical solution "designed to steer between the Scylla of compensation and the Charybdis of inconvenience," 2 but it was nevertheless one which was entirely consistent with contemporary social arrangements. For it consciously confirmed the separation of social classes which had been implicitly determined by the existing street pattern: Nash himself stressed that "the whole Communication from Charing Cross to Oxford Street will be a boundary and complete separation between the Streets and Squares occupied by the Nobility and Gentry, and the narrow Streets and meaner Houses occupied by mechanics and the trading part of the community." ${ }^{3}$ Nash, it is clear, had no sanitary zeal for the clearance of slums for its own sake; his avowed intention was, on the contrary, to contain and not to disperse them. When James Elmes published his eulogy on metropolitan improvements in 1828 and spoke of "the conversion of dirty alleys, dingy courts and squalid dens of misery and crime... into "stately streets" "4 he was not, therefore, identifying the main purpose of Regency street improvements but one of their incidental consequences.

The somewhat inconspicuous years coming between the death of both Nash and his patron in the early eighteen-thirties and the birth of the Metropolitan Board of Works in 1856 were not devoid of street improvement: Farringdon Road, Commercial Street, New Oxford Street, Victoria Street, and New Cannon Street were the most notable schemes either begun or completed during these years. Moreover, this was a period of not inconsiderable industry in the preparation and examination of scores of concrete proposals for both trifling and dramatic changes in the street plan of central London. Between I 832 and $185 \mathrm{I}$ a succession of parliamentary select committees issued between them some fifteen reports covering a wide variety of these schemes, of which twelve were ultimately carried through in modified form. This industrious planning involved the re-development of extensive areas, and although many schemes failed to pass the fine

1 First Report, R. C. on Metropolis Improvements, British Parliamentary Papers, 1844 (Is), xv, P. 9 .

2 J. Summerson, Architecture in Britain, 1530-1830, London I953, p. 299.

${ }^{3}$ First Report, H. M. Commissioners of Woods, Forests, and Land Revenues, I812, loc. cit., p. 89 .

4 J. Elmes, Metropolitan Improvements; or London in the Nineteenth century, London I828, pp. I-2. 
sieve of financial expediency, the evaluation of alternative proposals provides an adequate commentary on attitudes towards both the function and the mechanism of street improvement.

It is this evidence on the motivation of early Victorian street improvements which is at such variance with Napoleon's view. For even the most casual reading of these reports reveals the concern felt on all sides at the demonstrable relationship between housing conditions and public health; and, what is more, an examination of this evidence also shows the marked extent to which "improvers" relied on street improvement as the adjusting mechanism.

The Commissioners of Sewers for Finsbury, for example, wrote to the Privy Council in 1835 to say that an extension of Farringdon Street would not only provide a trunk route right through Central London to St. George's Fields in Southwark and thus provide an excellent means of communication between north and south London, but added that such an improvement was "far more important as relating to the health of that part of the capital through which it would be made, by the removal of a description of buildings that have long been a hotbed of disease, misery and crime." 1 Similar officials in Westminster evidently shared such views in respect of the proposed New Oxford Street through St. Giles'. ${ }^{2}$ As for the future Charing Cross Road, a resident of Bedford Square declared that its traversing Seven Dials "appears so necessary that almost every person in London, who has submitted any plan of improvement in that part of the town, has adopted the same plan." 3 This general attitude was explicitly stated by the Select Committee of ${ }_{1} 838$ in its second report: the Committee did not "confine themselves to the single purpose of obtaining increased facilities of communication" but considered that "other public benefits might in some cases be derived simultaneously with that principal object" 4, in particular the partial clearance of the "Rookery" of St. Giles' by means of an extension of Oxford Street to Hart Street. ${ }^{5}$ They based these conclusions on a mass of evidence they had taken on the desirability of promoting such street improvement schemes as improved both public health and morals, and they had been regaled by first-hand accounts of the brutish horrors of slum

1 Report, S. C. (H. C.) on Metropolis Improvements, British Parliamentary Papers, 1836 , $\mathrm{xx}, \mathrm{QQ} .8,20$.

${ }^{2}$ Ibid., QQ. $21,285$.

3 Ibid., Q. 375 .

4 Second Report, S. C. (H. C.) on Metropolis Improvements, British Parliamentary Papers, I $837-8$, xvi, p. iii.

5 Ibid., vii. 
life in various parts of central London. It was hardly surprising, therefore, that they insisted that "the most important improvements... are in direct proportion to the degree in which they embrace all the great purposes of amendment in respect of health and morals... by the removal of congregations of vice and misery, and the introduction of a better police." 1

The acceptance of this rough-and-ready criterion of desirability in street improvements naturally affected both the layout of new streets and the degrees of priority accorded to different schemes. Thus it was that when, for reasons of financial expediency, ${ }^{2}$ the programme of improvements had to be drastically reduced, schemes were judged according to "several objects of public utility, viz. I. The opening or enlarging of communications for the general convenience of public intercourse; 2. The improvement of certain districts, of which the present state is greatly injurious to the health of the inhabitants; 3. The melioration of the moral conditions of the labouring classes closely congregated in such districts." ${ }^{3}$ More than this, the line taken by new streets was generally determined by its effectiveness in clearing as many slum dwellings as possible. When James Pennethorne, whose early training had been under Nash, was being closely questioned by the Royal Commission on Metropolitan Improvements in I845 on his choice of the line for the future Victoria Street, he was asked, "But you did not look to the means of local communication, or of architectural ornament or development?" His answer was, "No; I regarded solely the sanatory question. My object has only been to ascertain how best to improve the condition of the inhabitants of Westminster by improving the buildings, the levels, and the sewers, and by opening communications through the most crowded parts." 4 The Commissio-

1 Ibid., viii.

2 This was a formative stage in the financial development of public works of this kind: the largest single source of income was the London Bridge Approaches Fund formed mainly from the proceeds of a duty on all coal brought into London; this was supplemented by local rates, private subscriptions, and loans raised on the security of the coal duties and of the land revenues of the Crown. Details of metropolitan improvements financed by the coal duties before 1838 may be found in Report, S.C. (H.C.) on the Coal Trade (Port of London) Bill, British Parliamentary Papers, 1837-8 (475), xv, Appendix No. 5; further details are available in Seventh Report, R.C. on Metropolis Improvements, British Parliamentary Papers, 185 I (1 356 ), xxix, Appendix.

${ }^{3}$ First Report, S.C. (H.C.) on Metropolis Improvements, British Parliamentary Papers, $184^{\circ}\left(4^{10}\right)$, xii, p. v.

4 Second Report, R.C. on Metropolis Improvements, British Parliamentary Papers, i 845 (348), xvii, QQ. 31, 40. Pennethorne continued to have an eye for this type of street improvement: some of his suggestions in the Covent Garden improvement, for example, were aimed primarily at slum clearance: Seventh Report, R.C. on Metropolis Improvements, 1851 , loc. cit., p. 5 . 
ners evidently endorsed Pennethorne's proposals, for in justifying a slight modification of the memorialists' original scheme they pointed out that "its effect has been to divert the channel of communication in a direction further south, into a more imperfectly drained, a more densely peopled, and consequently a more objectionable portion of the district." 1

The objects of street improvement in early Victorian London were seldom single, for street improvement during these years provided almost the only effective way of rectifying on a grand scale some of the worst features of urban growth. ${ }^{2}$ The disjointed maze of streets in central London was not only inefficient for transport and frustrating for the police but prodigal of human life. Thus, street improvement became not merely a method of increasing the circulation of traffic but a blunt, though seemingly effective, instrument of slum clearance. The naive expectation that, merely by redrawing the street map of London at key points, both the traffic and slum problems could be solved together had, it is true, a short life, while the problems themselves have had unwanted longevity. But while this hope prevailed schemes for street improvement were scrutinized for their effectiveness in ventilating the rookeries of central London.

What chiefly distinguished Parisian and London street improvements in this respect was not so much their sanitary aims, nor their conspicuous failure to obliterate slums (which were generally merely displaced, often in aggravated forms, to other localities, ${ }^{3}$ but the size of the budgets available to each, and the powers exercised by the planning authorities. For, unlike the grandiose schemes of Napoleon III which, by importunate borrowing and dubious book-keeping, could tap not only the savings of private investors but the vast reservoir of imperial funds, ${ }^{4}$ the schemes of early Victorian London had to be financed by borrowing on the open market, and not by subventions from the State. But the creation of an authority able to use the draconian measures of the Second Empire involved political decisions which were quite alien to the temperament which had produced the pusil-

1 Ibid., p.iv.

2 Metropolitan railways, it is worth adding, were also regarded in this role: see $\mathrm{H}$. $\mathrm{J}$. Dyos, Railways and Housing in Victorian London, in: Journal of Transport History, ii (1955), Nos. I and 2, pp. I I-2 I, 90-100.

3 Brian Chapman, Baron Haussmann and the Planning of Paris, in: Town Planning Review, xxiv (1953-4), p. I9I ; and S. E. Rasmussen, London, The Unique City, and ed., London 1948, pp. 134-5. Cf. Dyos, loc. cit., passim, and Some Social Costs of Railway Building in London, in: Journal of Transport History, iii (1957), pp. 25-30.

4 See David H. Pinkney, Money and Politics in the Rebuilding of Paris, 1860-187o, in: Journal of Economic History, xvii (1957), pp. 45-61 ; and Chapman, loc. cit., pp. I89-90. 
laminous Metropolitan Board of Works. ${ }^{1}$ The Times, envious of the Parisian street improvements, was apparently prepared in $186 \mathrm{I}$ for the creation of an authority which "would have strength enough to double the work of Hercules, and to cleanse not only the filthy stables, but the river which runs through them." 2 Two cardinal tenets of contemporary Liberal faith were, however, the need for scrupulous governmental economy and the avoidance of transfer payments in all schemes of social reform. ${ }^{3}$ Street improvement was, it is true, already forcing some people to re-examine their political axioms and to advocate principles of public finance and administration which would permit current social problems to be tackled realistically ${ }^{4}$; but, until these new concepts of social obligation had been fashioned and accepted, schemes for public betterment like street improvement were bound to be limited both financially and administratively. Commenting on the finance of Parisian street improvements, a legislator of the old school told the British Association in $186_{3}$ : “The state has come to the assistance of the city in this matter; but it can only be by casting the burthen upon the taxpayers of the country generally - a course which may be tolerated in a highly centralized country, like France, where, in fact, Paris is everything, and the rest of the nation nothing in comparison with it - but which would hardly be tolerated in England, where we pride ourselves on making every place pay for its own improvements." 5

Street improvement in early Victorian London had, therefore, to serve more than one end: the premium which financial expediency placed on proposals which were aimed solely at solving traffic problems, caused street improvement to be identified during these years in the twin rôle of improving both communications and public health.

1 [Unsigned] The Financial Question of the Works in Paris, in: The Builder, xxi (1863), p. 874; and [Editorial] A Quarter of a Centry of London Street Improvement, in: Ibid., xxiv (1866), p. 877.

2 The Times, 25 February i 86I (ed.).

3 See W. Ashworth, The Genesis of Modern British Town Planning, London I954, p. 65 seq.

${ }^{4}$ [Unsigned] The Question between London and Paris Improvements, in: The Builder, xix (1861), p. 870; [Editorial] A Quarter of a Century of London Street Improvement, loc. cit., pp. 898-9; Report of Meeting of Royal Institute of British Architects, I 8 December 1871 , in: The Builder, $x \times x$ (1872), pp. 22-4.

5 W. Tite, On the Paris Street Improvements, and their Cost, in: Journal of the Statistical Society, xxvii (1 864), p. 385 . 